OPEN ACCESS

Edited by: Vicent Arbona,

Jaume I University, Spain

Reviewed by:

Dennis H. Greer,

Charles Sturt University, New Zealand Elif Öztetik,

Anadolu University, Turkey

*Correspondence:

ZhaoLong Wang

tur@@situ.edu.cn

Specialty section: This article was submitted to

Plant Abiotic Stress,

a section of the journa

Frontiers in Plant Science

Received: 26 November 2016 Accepted: 19 January 2017

Published: 03 February 2017

Citation:

Dong Q, Xu PX and Wang ZL (2017) Differential Cadmium Distribution

and Translocation in Roots and Shoots Related

to Hyper-Tolerance between Tall

Fescue and Kentucky Bluegrass.

Front. Plant Sci. 8:113.

doi: 10.3389/fpls.2017.00113

\section{Differential Cadmium Distribution and Translocation in Roots and Shoots Related to Hyper-Tolerance between Tall Fescue and Kentucky Bluegrass}

\author{
Qin Dong ${ }^{1}$, PeiXian $X^{1,2}$ and ZhaoLong Wang ${ }^{1 *}$ \\ ${ }^{1}$ School of Agriculture and Biology, Shanghai Jiao Tong University, Shanghai, China, ${ }^{2}$ Shanghai Administration Department \\ of Green City, Shanghai, China
}

Phytoremediation efficiency mainly depends upon mechanisms in the uptake and translocation of soil contaminants. Cadmium (Cd) distribution and translocation in roots and shoots of tall fescue (Festuca arundinacea) and Kentucky bluegrass (Poa pratensis) were observed using fluorescence spectroscopy with a laser confocal scanning microscope. No difference in root $\mathrm{Cd}$ accumulations was detected between these two turfgrass species. Kentucky bluegrass transported more Cd into the stele for root-to-shoot translocation and resulted in significantly higher Cd concentration in leaves. In tall fescue, less Cd was transported into the stele in roots and more Cd was excreted to the cuticle layer in leaves. These results suggested that both turfgrass species were hypertolerant to Cd through distinct distribution patterns in leaves and roots.

Keywords: cadmium, fluorescence, cellular distribution, translocation, hyper-tolerance, tall fescue, Kentucky bluegrass

\section{INTRODUCTION}

Cadmium (Cd) pollution is one of the most serious environmental problems and there were approximately 20 million hectares of cultivated lands contaminated by Cd (Yu et al., 2006; Xue et al., 2014; Liu et al., 2015). Phytoremediation is a cost-effective and environment-friendly remediation technique for soil Cd contamination (Salt et al., 1998; Wan et al., 2016). Plants can absorb, translocate, sequestrate, degradate and extract contaminants from the contaminated soil without any damage of soil physical and chemical properties. After that, plants can be harvested, and processed by drying, ashing or composting. Some metals can be reclaimed from the ash (Raskin et al., 1997). The efficiency of phytoremediation mainly depends upon the capacities of plants (hyperaccumulators) to take up the heavy metal and remove from the soil (Bell et al., 2014). The plant extraction and tolerance to Cd involve many processes, which include $\mathrm{Cd}$ movement and availability in the soil, $\mathrm{Cd}$ absorption and accumulation in root tissues, $\mathrm{Cd}$ translocation from roots to the above-ground shoots via the vascular system, Cd detoxification and deposit in shoot tissues (Lux et al., 2011; Zhou et al., 2015; Cornu et al., 2016). 
Cadmium is very toxic to plants and the Cd-tolerant threshold in most reported hyperaccumulators were below $25 \mathrm{mg} \mathrm{kg}^{-1}$ of soil (Wei et al., 2004, 2008, 2009). Our pervious study showed that tall fescue (Festuca arundinacea) and Kentucky bluegrass (Poa pratensis) could tolerate up to 200 and $100 \mathrm{mg} \mathrm{kg}^{-1}$ of soil Cd concentration, respectively, without any significant decline of turf quality (Xu et al., 2014). Plants of tall fescue and Kentucky bluegrass accumulated 44.5- and 40.8-fold more Cd than Cd hyperaccumulator, Solanum nigrum, without any toxic symptoms (Xu and Wang, 2014). These results indicated that tall fescue and Kentucky bluegrass could be good candidate plants for phytoextraction or phytostabilization of $\mathrm{Cd}$ contaminated soils. However, it is still unclear about the mechanism of $\mathrm{Cd}$ hypertolerance in these two turfgrass species.

Cadmium distribution in plants tissues and cells is important for understanding the mechanism of hypertolerance. Therefore, the objectives of this study were (i) to observe in situ Cd distribution and translocation in roots and leaf tissues, (ii) interpret the differences of Cd hypertolerance between tall fescue and Kentucky bluegrass.

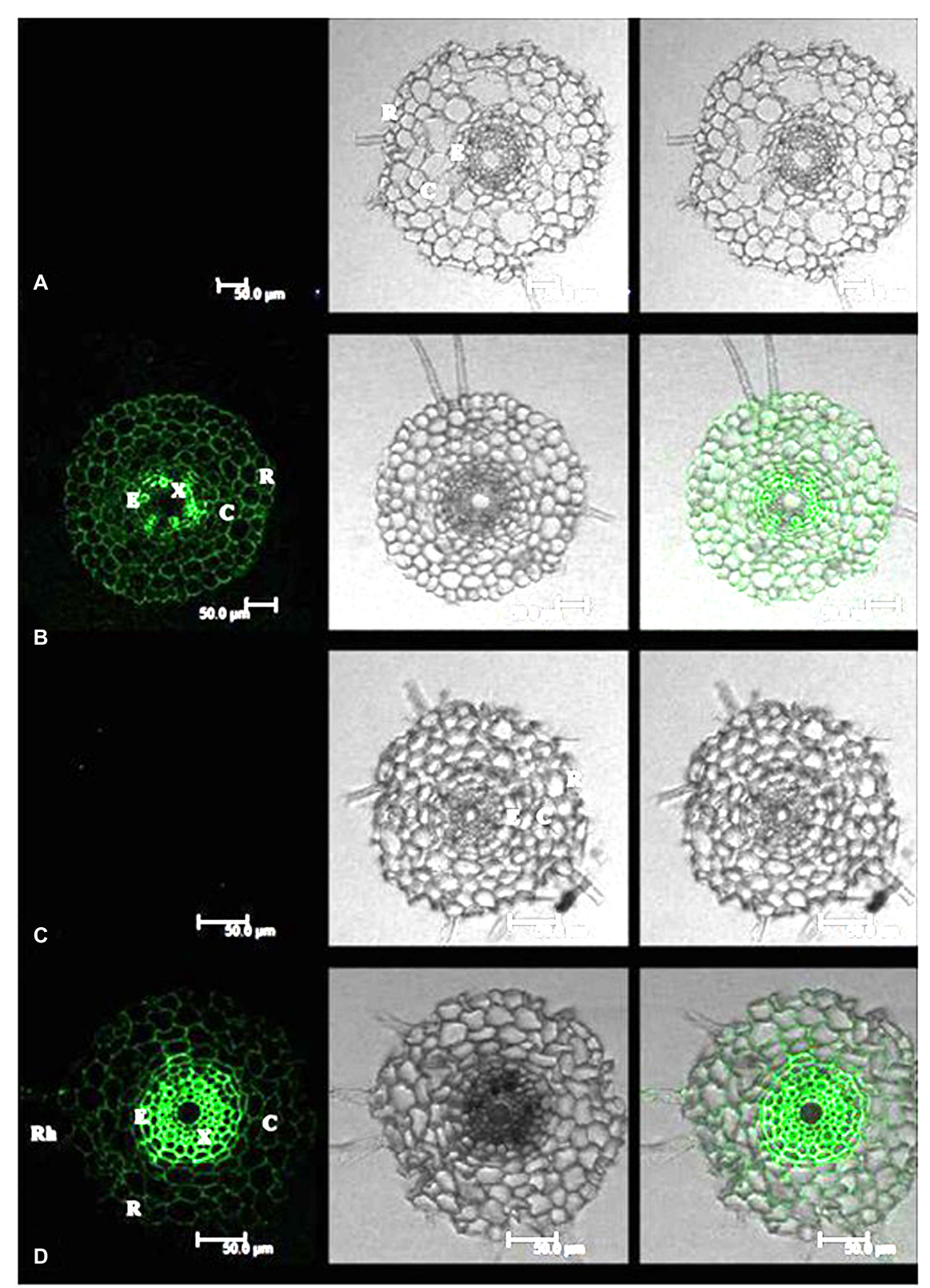

FIGURE 1 | Cadmium (Cd) distributions in the root tissues of tall fescue (A,B) and Kentucky bluegrass (C,D). (A) Tall fescue control; (B) tall fescue Cd treatment under $0.3 \mathrm{mM} \mathrm{Cd}^{2+}$ for 7 days; (C) Kentucky bluegrass control; (D) Kentucky bluegrass Cd treatment under $0.3 \mathrm{mM} \mathrm{Cd}^{2+}$ for 7 days. R, rhizodermis; C, cortex; E, endodermis; X, xylem. Left column: Cd fluorescence image; Middle column: root transverse sectional image; Right column: combined image with Cd fluorescence and root section. 


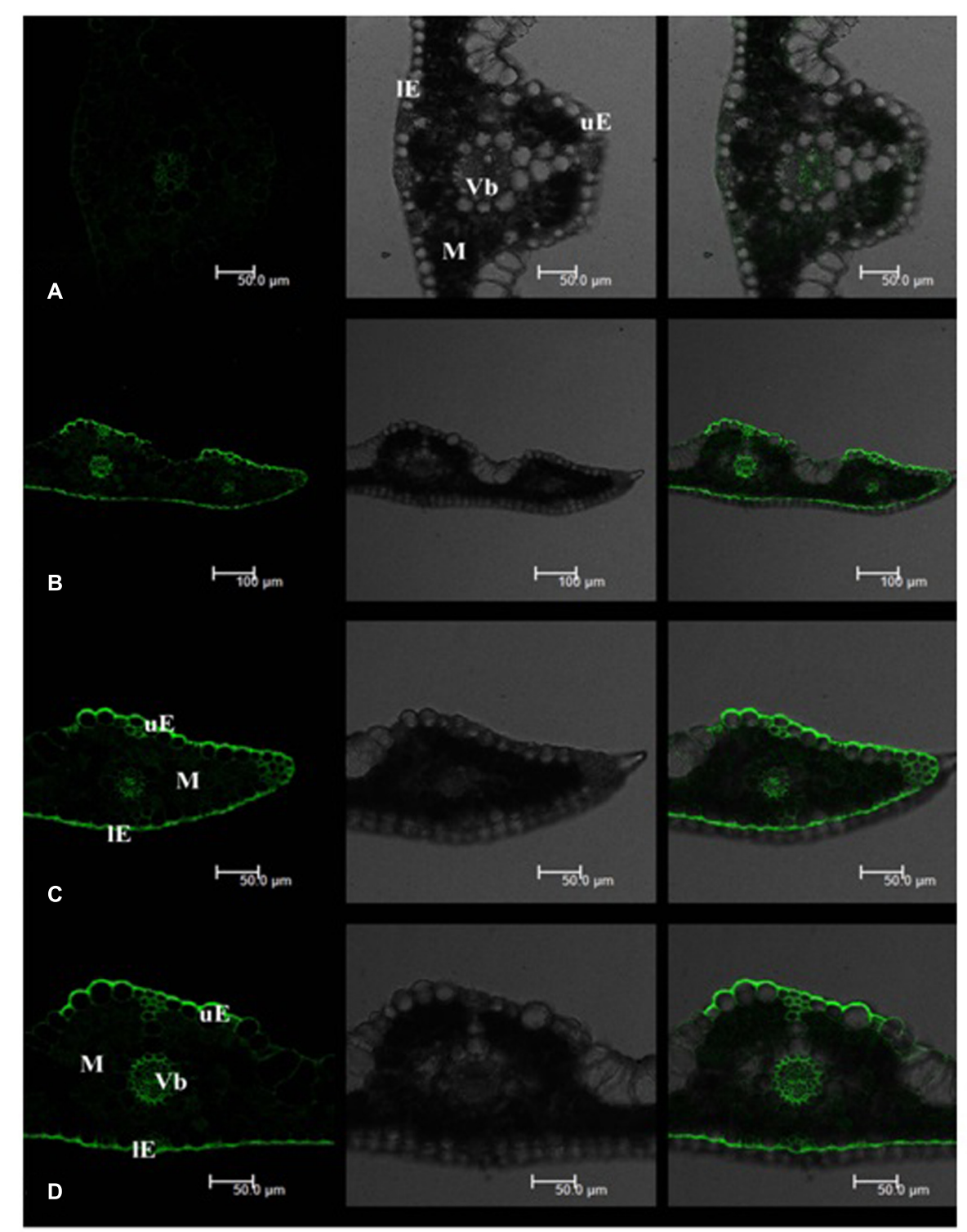

FIGURE 2 | Cadmium distributions in the leaf tissues of tall fescue. (A) Tall fescue control; (B-D) tall fescue Cd treatment under 0.3 mM Cd ${ }^{2+}$ for 7 days. uE, upper epidermis; IE, lower epidermis; M, mesophyll; Vb, vascular bundle. Left column: Cd fluorescence image; Middle column: leaf transverse sectional image; Right column: combined image with Cd fluorescence and leaf section.

\section{MATERIALS AND METHODS}

Tall fescue (cv. Barlexas) and Kentucky bluegrass (cv. Midnight) were planted in sand-based fields. Mature plants were transplanted into a hydroponic culture system in this study. After roots and old leaves were removed, plants were transplanted into $5 \mathrm{~L}$ plastic pots containing $1 / 2$ strength Hoagland's nutrient solution (Hoagland and Arnon, 1950) with aeration to induce new root development in growth chambers.

The growth chambers used in this experiment were constructed under the Chinese National Standard (GB/T 32710.6-2016 and GB/T 32710.7-2016). There were13 sensors (temperature, irradiation, humidity, $\mathrm{CO}_{2}$ ) evenly distributed in the $3 \mathrm{~m} \times 3 \mathrm{~m}$ growth chamber to monitor the environmental variables in the growth chamber. All environmental parameters were controlled by the artificial intelligence programs and were calibrated each month. During the whole experimental period, the variations of all monitored environmental parameters in the growth chamber were controlled $\leq 5 \%$ at the canopy level. In the experiment, canopy temperature was controlled at $25 / 20 \pm 2{ }^{\circ} \mathrm{C}$ (day/night). Canopy photosynthetically active radiation was controlled at $400 \mu \mathrm{mol} \mathrm{m}{ }^{-2} \mathrm{~s}^{-1}$ with 14 -h photoperiod. Relative humidity was controlled at $75 \pm 2 \%$.

After new roots were developed and reached above $10 \mathrm{~cm}$ long, plants were transferred to the modified $1 / 2$ strength Hoagland's nutrient solution containing $0.3 \mathrm{mM} \mathrm{Cd}^{2+}$ supplied in the form 


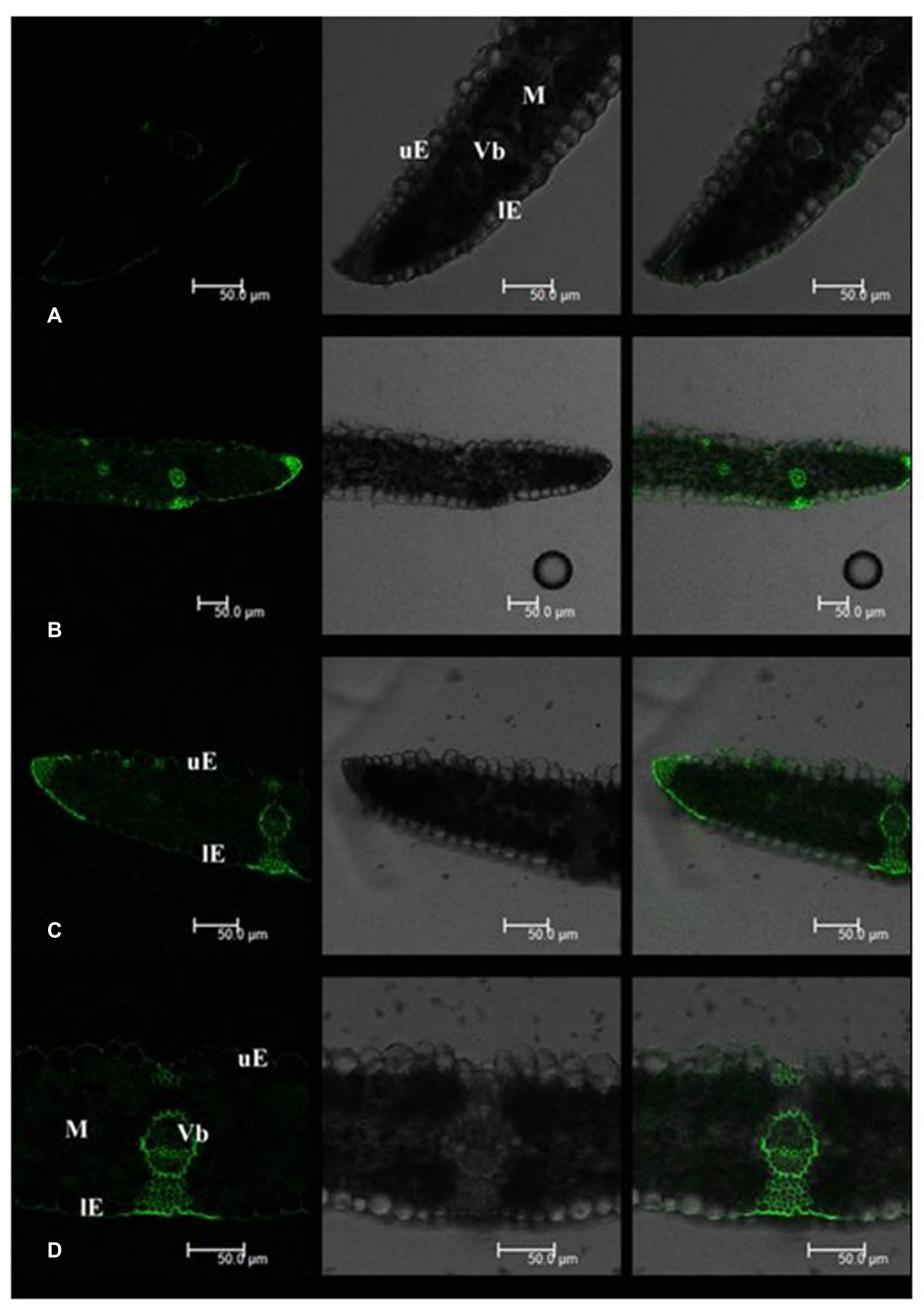

FIGURE 3 | Cadmium distributions in the leaf tissues of Kentucky bluegrass. (A) Kentucky bluegrass control; (B-D) Kentucky bluegrass Cd treatment under $0.3 \mathrm{mM} \mathrm{Cd}^{2+}$ for 7 days. uE, upper epidermis; IE, lower epidermis; M, mesophyll; Vb, vascular bundle. Left column: Cd fluorescence image; Middle column: leaf transverse sectional image; Right column: combined image with Cd fluorescence and leaf section.

of $\mathrm{CdCl}_{2}$. The control group was maintained under the same environmental conditions, except without the addition of $\mathrm{CdCl}_{2}$. All treatments and controls were replicated four times in the experiment. The nutrient solution was renewed every week and the $\mathrm{pH}$ was adjusted to 6.5 with $0.1 \mathrm{M} \mathrm{HCl}$ or $0.1 \mathrm{M} \mathrm{NaOH}$.

Cadmium fluorescence observation was conducted according to Xiong et al. (2009). After 7 days of Cd treatment, fresh roots and the first fully expanded leaves were sampled for cross section with freezing microtome. All sections were $40 \mu \mathrm{m}$ thick and were stained with the assay reagent from the LEADMIUM kit (Invitrogen) for $60 \mathrm{~min}$ in the dark and then washed three times with assay buffer for 5 min each time. Samples were observed with a laser confocal scanning microscope (Leica TCS SP5-II) with excitation and emission wavelengths of 488 and $520 \mathrm{~nm}$, respectively. 
After 60 days of $\mathrm{Cd}$ treatment, plants were harvested and separated into roots and shoots. The roots were immersed in $20 \mathrm{mM}$ EDTA-Na 2 solution for $15 \mathrm{~min}$ to remove $\mathrm{Cd}$ that was adhered to the root surface ( $\mathrm{Xu}$ and Wang, 2013), washed with deionized water and then dried with an absorbent paper. The roots and shoots were dried at $100^{\circ} \mathrm{C}$ for $10 \mathrm{~min}$ and $80^{\circ} \mathrm{C}$ to a constant weight in an oven. Dry samples were ground, passed through a 100 -mesh $(0.15 \mathrm{~mm})$ sieve and digested in supra-pure concentrated $\mathrm{HNO}_{3}$ and $\mathrm{HClO}_{4}$ (4:1, $\mathrm{v} / \mathrm{v})$ at $130-150^{\circ} \mathrm{C}$ and diluted to $100 \mathrm{~mL}$. The concentration of Cd was determined using inductively coupled plasmaatomic emission spectroscopy (ICP-AES, iCAP6300, Thermo, USA).

The hydroponic experiment was repeated three times in a 2-years period. A histochemical method was used for Cd detection in the first experiment (Supplementary Data sheet 1) according to Seregin and Kozhevnikova (2011). The photos presented in the paper were from Cd fluorescence method (Xiong et al., 2009) in the second experiment, which showed more clear $\mathrm{Cd}$ distribution in plant tissues. The third repeated experiment was conducted for observation of the pathway of leaf excretion. The roots and shoots were harvested to determine the $\mathrm{Cd}$ concentrations in all three repeated experiments and the repeated experiments showed the same results. The Cd data presented in this paper was from the same samples used for Cd fluorescence observation in the second repeated experiment.

All data are presented as means of four replicates. Statistical analysis were performed with the software SAS (version 9.1, SAS Institute Inc., Cary, NC, USA) using the general linear model (GLM) procedure. Least significance difference (LSD) at a 0.05 probability level was used to detect the differences between treatment means.

\section{RESULTS}

Cadmium fluorescence was clearly observed in the epidermis, cortex and stele of roots in both tall fescue and Kentucky bluegrass (Figure 1). No fluorescence was observed in control plants, indicating that the fluorescence spectroscopy is a specific reliable method for Cd localization in plant tissues. In roots of tall fescue, $\mathrm{Cd}$ fluorescence showed even distribution in the epidermis, cortex, and stele; the strongest $\mathrm{Cd}$ fluorescence was observed in xylem vessels in the stele (Figure 1B). Cd fluorescence in root tissues of Kentucky bluegrass showed an uneven distribution, with much stronger $\mathrm{Cd}$ fluorescence in the stele and less fluorescence in the epidermis and cortex (Figure 1D).

Leaf Cd fluorescence showed uneven patterns in both tall fescue and Kentucky bluegrass (Figures 2 and 3). In tall fescue leaves, the strongest $\mathrm{Cd}$ fluorescence was observed in vascular bundles and the epidermis. Mesophyll tissues showed the weakest $\mathrm{Cd}$ fluorescence (Figure 2). There was very strong $\mathrm{Cd}$ fluorescence in the cuticle layer of epidermis all around the leaf surface in tall fescue. In Kentucky bluegrass

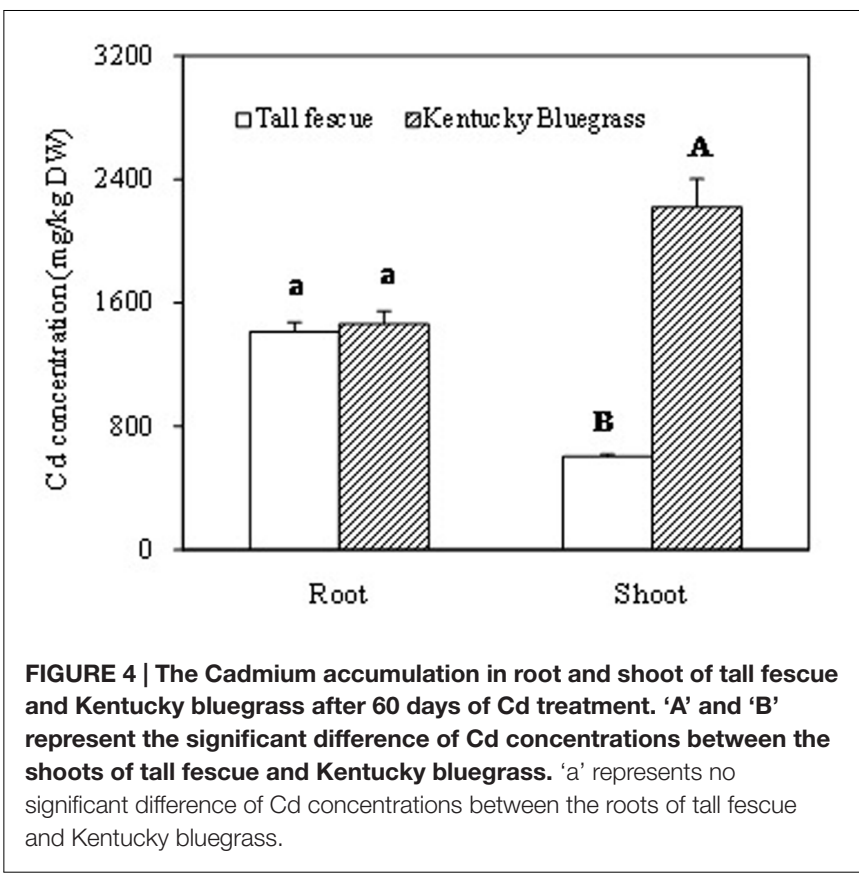

leaves, the strongest $\mathrm{Cd}$ fluorescence was detected in veins and leaf margins (Figure 3). There was much weaker Cd fluorescence in the epidermis between veins than that within the vein and leaf margins. Mesophyll tissues showed stronger Cd fluorescence in Kentucky bluegrass compared with those in tall fescue.

After 60 days of Cd treatment, root Cd concentration showed no significant difference between tall fescue and Kentucky bluegrass (Figure 4). However, shoot $\mathrm{Cd}$ concentration in Kentucky bluegrass was significantly higher than that in tall fescue. Kentucky bluegrass shoot accumulated about 3.7-fold higher amount of Cd than tall fescue.

\section{DISCUSSION}

Cadmium can be absorbed into the rhizodermis and cortex of roots either via apoplastic or symplastic pathways (Kushwaha et al., 2016), but it must pass through the plasma membrane of the endodermis cell before entering the stele of roots for longdistance transport (Verbruggen et al., 2009; Xu and Wang, 2013). The Cd binding by cell walls of rhizodermis and cortex tissues may serve as the first barrier to reduce the active $\mathrm{Cd}^{2+}$ and lessen the damage to root cells and/or the amount of $\mathrm{Cd}^{2+}$ transported into the stele (Nishizono et al., 1989; Verkleij and Schat, 1990). In this study, Kentucky bluegrass showed the strongest Cd fluorescence in the stele and less fluorescence in epidermic and cortical tissues (Figure 1D), indicating that the most Cd absorbed by roots was transported into the stele for further root-toshoot translocation, as shown by the higher $\mathrm{Cd}$ concentration accumulated in leaves of Kentucky bluegrass (Figure 4).

Mesophyll is the critical functional tissues in the leaf for photosynthesis (Ebbs et al., 2009). The weaker Cd fluorescence in mesophyll tissues of tall fescue indicated that the photosynthetic 
apparatus in tall fescue might suffer less Cd toxicity than that in Kentucky bluegrass.

Qi et al. (2014) reported that Rhodes grass (Chloris gayana) could excrete salt out of the cuticle surface via salt glands. In this study, we observed strong Cd fluorescence in the cuticle layer of the leaf epidermis, which indicated that tall fescue and Kentucky bluegrass could excrete Cd out of the leaf tissues to avoid Cd damages. More uniform and stronger $\mathrm{Cd}$ fluorescence in the cuticle layer of tall fescue leaves indicated the higher capacity of Cd excretion. The mechanisms of how leaves of these two turfgrass species to excrete $\mathrm{Cd}$ to the leaf surface are unclear, which deserves further investigation.

\section{CONCLUSION}

There was no difference in root Cd accumulations between tall fescue and Kentucky bluegrass. Kentucky bluegrass transported more $\mathrm{Cd}$ into the stele and translocated from roots to shoots, resulting in significantly higher $\mathrm{Cd}$ concentrations in leaves, compared with tall fescue. The less Cd transported into the stele in roots and more $\mathrm{Cd}$ excreted to the cuticle layer in the leaf of tall fescue could contribute to its high level of Cd hypertolerance.

\section{REFERENCES}

Bell, T. H., Joly, S., Pitre, F. E., and Yergeau, E. (2014). Increasing phytoremediation efficiency and reliability using novel omics approaches. Trends Biotechnol. 32, 271-280. doi: 10.1016/j.tibtech.2014.02.008

Cornu, J. Y., Bakoto, R., Bonnard, O., Bussiere, S., Coriou, C., Sirguey, C., et al. (2016). Cadmium uptake and partitioning during the vegetative growth of sunflower exposed to low Cd2+ concentrations in hydroponics. Plant Soil 404, 263-275. doi: 10.1007/s11104-016-2839-8

Ebbs, S. D., Zambrano, M. C., Spiller, S. M., and Newville, M. (2009). Cadmium sorption, influx, and efflux at the mesophyll layer of leaves from ecotypes of the Zn/Cd hyperaccumulator Thlaspi caerulescens. New Phytol. 181, 626-636. doi: 10.1111/j.1469-8137.2008.02693.x

Hoagland, D. R., and Arnon, D. I. (1950). The water-culture method for growing plants without soil. Calif. Agric. Exp. Stn Circ. 347, 1-32.

Kushwaha, A., Rani, R., Kumar, S., and Gautam, A. (2016). Heavy metal detoxification and tolerance mechanisms in plants: implications for phytoremediation. Environ. Rev. 24, 39-51. doi: 10.1139/er-2015-0010

Liu, Y., Xiao, T., Baveye, P. C., Zhu, J., Ning, Z., and Li, H. (2015). Potential health risk in areas with high naturally-occurring cadmium background in southwestern China. Ecotoxicol. Environ. Saf. 112, 122-131. doi: 10.1016/j. ecoenv.2014.10.022

Lux, A., Martinka, M., Vaculik, M., and White, P. J. (2011). Root responses to cadmium in the rhizosphere: a review. J. Exp. Bot. 62, 21-37. doi: 10.1093/jxb/ erq281

Nishizono, H., Kubota, K., Suzuki, S., and Ishii, F. (1989). Accumulation of heavy metals incell walls of Polygonum cuspidatum roots from metalliferous habitats. Plant Cell Physiol. 30, 595-598.

Qi, T., Miyake, H., and Taniguchi, M. (2014). Salt excretion through the cuticle without disintegration of fine. structures in the salt glands of Rhodes grass (Chloris gayana Kunth). Flora 209, 185-190. doi: 10.1016/j.flora.2014. 02.004

Raskin, I., Smith, R. D., and Salt, D. E. (1997). Phytoremediation of metals: using plants to remove pollutants from the environment. Curr. Opin. Biotechnol. 8, 221-226. doi: 10.1016/S0958-1669(97)80106-1

Salt, D. E., Smith, R. D., and Raskin, I. (1998). Phytoremediation. Annu Rev. Plant Biol. 49, 643-668. doi: 10.1146/annurev.arplant.49.1.643

\section{AUTHOR CONTRIBUTIONS}

PX and ZW conceived and designed the experiment. QD and PX conducted the experiment. QD and ZW analyzed data and wrote the manuscript. The authors read and approved the paper.

\section{FUNDING}

This work was financially supported by the National Natural Science Foundation of China Grant 31472143.

\section{ACKNOWLEDGMENT}

The authors are thankful for Dr. Bingru Huang at Rutgers University for manuscript improvement.

\section{SUPPLEMENTARY MATERIAL}

The Supplementary Material for this article can be found online at: http://journal.frontiersin.org/article/10.3389/fpls.2017.00113/ full\#supplementary-material

Seregin, I. V., and Kozhevnikova, A. D. (2011). Histochemical methods for detection of heavy metals and strontium in the tissues of higher plants Russ. J. Plant Physiol. 58, 721-727.

Verbruggen, N., Hermans, C., and Schat, H. (2009). Molecular mechanism of metal hyperaccumulation in plants. New Phytol. 181, 759-776. doi: 10.1111/j.14698137.2008.02748.x

Verkleij, J., and Schat, H. (1990). "Mechanisms of metal tolerance in higher plants," in Heavy Metal Tolerance in Plants: Evolutionary Aspects, ed. A. J. Shaw (Boca Raton, FL: CRC Press), 179-193.

Wan, X. M., Lei, M., and Chen, T. B. (2016). Cost-benefit calculation of phytoremediation technology for heavy-metal-contaminated soil. Sci. Total Environ. 563, 796-802. doi: 10.1016/j.scitotenv.2015.12.080

Wei, S. H., Niu, R. C., Srivastava, M., Zhou, Q. X., Wu, Z. J., Sun, T. H., et al. (2009). Bidens tripartita L.: a Cd accumulator confirmed by pot culture and site sampling experiment. J. Hazard. Mater. 170, 1269-1272. doi: 10.1016/j.jhazmat. 2009.05.078

Wei, S. H., Zhou, Q. X., and Mathews, S. (2008). A newly found cadmium accumulator-Taraxacum mongolicum. J. Hazard. Mater. 159, 544-547. doi: 10.1016/j.jhazmat.2008.02.052

Wei, S. H., Zhou, Q. X., Wang, X., Cao, W., Ren, L. P., and Song, Y. F. (2004). Potential of weed species applied to remediation of soils contaminated with heavy metals. J. Environ. Sci. (China) 16, 868-873.

Xiong, J., An, L. Y., Lu, H., and Zhu, C. (2009). Exogenous nitric oxide enhances cadmium tolerance of rice by increasing pectin and hemicellulose contents in root cell wall. Planta 230, 755-765. doi: 10.1007/s00425-0090984-5

Xu, P. X., Fei, L., Chen, X. P., and Wang, Z. L. (2014). Cadmium tolerance and accumulation in four cool-season turfgrasses. Acta Pratacul. Sin. 6, $176-188$.

Xu, P. X., and Wang, Z. L. (2013). Physiological mechanism of hypertolerance of cadmium in Kentucky bluegrass and tall fescue: chemical forms and tissue distribution. Environ. Exp. Bot. 96, 35-42. doi: 10.1016/j.envexpbot.2013.09.001

Xu, P. X., and Wang, Z. L. (2014). A comparison study in cadmium tolerance and accumulation in two cool-season turfgrasses and Solanum nigrum L. Water Air Soil Poll. 225:1938. doi: 10.1007/s11270-014-1938-5

Xue, D., Jiang, H., Deng, X., Zhang, X., Wang, H., Xu, X., et al. (2014). Comparative proteomic analysis provides new insights into cadmium accumulation in rice 
grain under cadmium stress. J. Hazard. Mater. 280, 269-278. doi: 10.1016/j. jhazmat.2014.08.010

Yu, H., Wang, J., Fang, W., Yuan, J., and Yang, Z. (2006). Cadmium accumulation in different rice cultivars and screening for pollution-safe cultivars of rice. Sci. Total Environ. 370, 302-309. doi: 10.1016/j.scitotenv.2006. 06.013

Zhou, C. F., Zhang, K., Lin, J. W., Li, Y., Chen, N. L., Zou, X. H., et al. (2015). Physiological responses and tolerance mechanisms to cadmium in Conyza Canadensis. Int. J. Phytorem. 17, 280-289. doi: 10.1080/15226514.2014. 898021
Conflict of Interest Statement: The authors declare that the research was conducted in the absence of any commercial or financial relationships that could be construed as a potential conflict of interest.

Copyright $\odot 2017$ Dong, Xu and Wang. This is an open-access article distributed under the terms of the Creative Commons Attribution License (CC BY). The use, distribution or reproduction in other forums is permitted, provided the original author(s) or licensor are credited and that the original publication in this journal is cited, in accordance with accepted academic practice. No use, distribution or reproduction is permitted which does not comply with these terms. 